Original Research Paper

\title{
The Development of Multiculturalism Values in Indonesian History Textbook
}

\author{
Didin Saripudin and Kokom Komalasari \\ Faculty of Social Sciences Education, Indonesia University of Education, Bandung, Indonesia
}

\author{
Article history \\ Received: 03-04-2016 \\ Revised: 24-06-2016 \\ Accepted: 25-06-2016 \\ Corresponding Author: \\ Didin Saripudin \\ Faculty of Social Sciences \\ Education, Indonesia \\ University of Education, \\ Bandung, Indonesia \\ Email: kalimaya36@yahoo.co.id
}

\begin{abstract}
History textbook is primary source of learning for students. It is expected to have a didactic-educative value for the formation of national identity and an ability to unify the collective experiences of a multicultural nation. Therefore, it is necessary to develop multiculturalism values in a history textbook. This study is aimed to develop models of an Indonesian history textbook that multiculturalism values. The study employed a Research and Development design at some high schools in West Java, Indonesia. Results reveal that multiculturalism-based history textbooks incorporate multiculturalism values (the diversity of historical characters and events; and the occurrence of historical, cultural and ethnic, religious and gender-related events) in accordance with competencies in the curriculum, principles of the preparation of textbook reference materials, language and readability and graphics. The book outline includes title of chapter, introduction, map of concepts and keywords. The materials presentation includes fact-concepts, principles and procedures-values of multiculturalism, competence, summary, reflection, authentic assessment, feedback and followup activities. The understanding of material and the development of multiculturalism values of learners can be categorized as very good.
\end{abstract}

Keywords: Values, Multiculturalism, Textbooks, Indonesian History, Culture, Ethnic, Gender

\section{Introduction}

A textbook of a particular field of study is a standard book written or compiled by experts for instructional purposes and objectives. It is equipped with tools and easily understood by users, whether in schools and colleges, to support learning program (Tarigan, 1986). In general, a textbook can be interpreted as the primary reference that students use in learning and teaching processes. A textbook is compiled and written for students by experts of certain specialties in order to facilitate the process of teaching and/or learning for students (Sjamsuddin, 2000).

Textbooks still serve as the main source used by teachers and students in supporting learning process, including in the field of history science. The role that history textbooks play is very strategic because they involve the formation of cognitive (intellectual) and affective (appreciation, values) domains of all learners from every level of education. National history, in particular, is considered to have didactic-educative value for the formation of national identity and an ability to unify the collective experiences of a multicultural nation (Sjamsuddin, 2000). The Indonesian history subject in the 2013 curriculum is crucial because it is a compulsory subject for all classes in high school.

Despite the fact that students are highly dependent on Indonesian history textbooks, its existence is only as a medium to achieve "the ultimate cognitive value" alone. Students have not been able to interpret the values for the formation of national identity. Socio-culturally, Indonesian people are pluralistic in terms of ethnicity, culture and religion. As has been known, Indonesian nationalism emerged as a counter movement to colonialism. However, nationalism is called into question due to the emergence of a variety of ethnic conflicts and strong spirit of regionalism. In order to accommodate the diversity that exists among the people into the history education, the concepts of ethnicity and nationality need to be redefined. The concepts are to describe people ethnic identity within the framework of togetherness and unity (Wiriaatmadja, 2004).

Purwanta (2012) in his research entitled Wacana Identitas Nasional: Analisis Isi Buku Teks Pelajaran Sejarah SMA 1978-2008 (Discourse of National Identity: Content Analysis of High School History Textbooks from 1978 to 2008) explains that historical explanation 
of diversity is still lacking. Lack of attention to ethnic diversity in the narrative of Indonesian history textbooks may convey the message to high school students that the birth of Indonesia was a political decision that occurred in 1945 Java by Javanese or non-Javanese who had undergone "Javanization". In other words, the current Indonesia identity is a political status under the dominance of the Javanese.

As a source of national identity education, materials in history textbooks should reflect the diversity of Indonesia within a collectivity framework in the history of Indonesian formation. Therefore, the contents of the book should not be dominated by history of a specific region, ethnicity, culture, race and religion. It is necessary to develop multiculturalism values in history textbooks. Hence, students can understand the nation history that was built in the collective diversity, as well as taking position in today and future as a part of a plural society that pays respects for diversity in the real life.

The development of multiculturalism values in history textbooks is based on several considerations. Firstly, cultural pluralism is not something that is "given", but it is a process of internalization of values in a community (Tilaar, 2005). The idea of "cultural pluralism" for Indonesia has begun to be source for thought since the National Revival period because of the complexity encapsulated in the "Youth Pledge". It was recognition of the reality, as well as ideals to be materialized (Wiriaatmadja, 2004). It shows that the internalization of diversity awareness values has been done for a long time and needs to be shown in history textbooks.

Secondly, the main reference for the realization of multicultural Indonesian people is multiculturalism. Multiculturalism is an ideology that recognizes and magnifies the differences in equality both individually and culturally. In this model of multiculturalism, a society is seen as a generally accepted culture in the community that is like a mosaic (Suparlan, 2005). The values of multiculturalism should be presented in history textbooks because Indonesian history is built based on multiculturalism (Supardan, 2005).

Thirdly, multicultural education should be included in history education for several reasons: (i) Changes of Indonesian human life are caused by economic and technological advances; (ii) the existence of displacement and mobility of the population is quite high; (iii) there is opening of rural areas; (iv) various socio-cultural conflicts that emerged lately show enormous cultural misunderstandings between the warring factions; and (v) myths and historical interpretation unfavorable to the unity of the nation need to be eliminated (Hasan, 2012).

Given the above-mentioned argumentation, a research and development study to produce a model of an Indonesian history textbook that develops the multiculturalism values is imperative. This article will hence describe the conceptual model, the contents of books and chapters and a limited trial of the textbook use of Indonesia History based on multiculturalism values.

\section{Material and Methods}

The research method is the Research and Development design. This article draws on the results of research in the first year of a planned three years of research. This article presents only the "exploration" that is only qualitative and quantitative descriptive, not up to the part of the "experiment", so the steps that are used only five of the ten-step Research and Develompment design from Borg and Gall (1989), namely: Research and information collecting, planning, develop preliminary form of product, preliminary field-testing and main product revision. Based on this process, the researchers perform: (1) Collect information to develop a conceptual model of history textbooks based on the multicultural values; (2) making Indonesian history textbook based multicultural values; (3) validate multicultural-based Indonesian history textbooks based on the Indonesian historical matter experts and learning experts; (4) use of Indonesian history textbooks based on multicultural values in limited school to obtain input from users (teachers and students); (5) improve Indonesian history textbooks based on the results of validation and feedback from users.

The location of study was in high school in West Java, Indonesia. Subjects were teachers and learners. The research sample was determined by a purposive sampling technique (to enable the high school to become a pilot project of the implementation of 2013 Curriculum). The sample included SMAN 15 Bandung, SMA Laboratorium UPI Bandung and SMA Pasundan 8 Bandung.

Data collection techniques covered observation, interviews, document analysis and Focus Group Discussion. Data was collected through a textbook assessment instrument adapted from the Centre for Curriculum and Books, the Ministry of Education and Culture. It included feasibility contents of the book and the book presentation instrument. Qualitative data analysis techniques employed an interactive model that consists of data collection, data reduction, data display and inference/verification (Miles and Huberman, 1984). The research also included descriptive quantitative analysis.

\section{Results}

Conceptual Model of the Development of Multiculturalism Values in Indonesian History Textbooks for High School

A multiculturalism-based Indonesian history textbook should conceptually integrate multiculturalism principles and values with regard to principles of scientific learning (requirement of learning in the 2013 
curriculum), to develop core and basic competence in line with 2013 curriculum, principles of preparation of textbook material, language and readability and graphics.

Following are some principles of writing of an Indonesian history textbook based on multiculturalism:

- Incorporating multiculturalism values in Indonesian history textbooks takes into account the diversity of historical characters and events, the occurrence of historical events, culture and ethnicity, religion and gender

- Banks (2002) approach in integrating multicultural values into a book covers Contributions Approach or "Heroes and Holiday"; Additive approach or "ethnic additive approach"; Transformative approach; and Decision making and social action approach

- The principles of learning in the writing of textbook includes readiness, motivation, use of a tool to focus attention (illustrations, colorful pictures, various texts), active learner participation, recurrence, feedback, interaction vision of social-cognitive, authentic assessment, reflection, life skills, observations, asking questions, gathering information, analysis, communication, model of project learning, problem solving and discovery

- Developing core and basic competencies in the 2013 curriculum is to establish knowledge about the material to be known and understood by learners. Skills cover the ability of developed practical knowledge, so that the acquired knowledge can be something meaningful because it can be used in dealing with the life problems and attitude. Every learner needs to learn and internalize values to support the effectiveness of participation in life

- The principles of textbook material preparation cover several things. First is accuracy: The material should be accurate in terms of science. Second is relevance: The material should be associated or relevant with standards and basic competencies to be achieved. Third is adequacy: The material adequately helps learners to achieve competence. Fourth is consistency: Type and amount of material are appropriate or consistent with the competencies to be achieved. Fifth is actuality: The material is to be kept abreast of the development of science and technology. Sixth is scientific structure: The sequence of material is in accordance with the structure of knowledge of each subject

- Language and readability are prepared to meet several criteria: (a) Sentences are in accordance with the rules of good and correct Indonesian language; (b) the structure of the sentences should indicate patterns of logical and systematic thinking; (c) the structure of the sentences is in accordance with the level of learner's language mastery; and (d) the sentences are communicative

\section{Framework of Multiculturalism-Based Indonesian History Textbook}

The framework of each chapter in the Indonesian history textbook is developed as follows.

The title of chapter/discussion is made meaningful:

- Introduction begins with images, stories, poems, cases and others. It is followed by apperception of material association and reflection of life values to be developed

- Map concepts and keywords are overviews of the material that will be presented and the multiculturalism values to be developed in the chapter/discussion

- The material presented in the book includes facts, concepts, principles, procedures and multiculturalism values.

- To draw appearance/performance of competencies, students are invited to perform a series of tasks/practices to develop competencies (knowledge, attitudes/values/character, thinking skills and participation skills)

- Summary contains conclusions of learning material that must be mastered and the multiculturalism values that should be developed

- Reflection/Contemplation covers reflection of the multiculturalism values practiced in daily life

- Authentic assessment contains a series of student assessment instruments (test, attitude scale and performances)

- Feedback provides answer keys and assessment forms that are accompanied by the assessment rubric

- Follow-up activities (transfers, enrichment, remedial) provide directions of material enrichment activities for those who have reached the expected competencies; and remedial for those who have not reached expected competencies

\section{Multiculturalism Values in History Textbooks}

The multiculturalism values developed in the history textbooks covers diversity of historical characters and events, the occurrence of historical events, culture and ethnicity, religion and gender. In more detail, the multiculturalism values in the history textbooks can be seen below.

\section{Figures in the History of Events}

The time of the national movement was an arena of the emergence of figures that reflected differences of ideology and region of national movement leaders. The Indonesian history textbook displays Dr. Wahidin Sudirohusodo nationalist Javanese figure) and Tan Malaka (a communist Sumatran wing figure). It can be seen in Fig. 1 . 
Golongan terpelajar ini mempunyai wawasan baru tentang nasionalisme Indonesia. Mereka ingin mengubah pandangan yang bersifat kedaerahan menjadi bersifat nasional. Untuk itu cita-cita kemerdekaan Indonesia hanya dapat dicapai apabila ada persatuan dan kesatuan bangsa. Kemudian, lahirlah Pergerakan Nasional, yang bertujuan untuk mencapai Indonesia Merdeka. Tokoh-tokoh dari golongan terpelajar ini kemudian mendirikan organisasi perjuangan, salah satunya adalah Dr. Wahidin Sudirohusodo. Ia juga berperan dalam mendirikan Studie Fonds. Kesadaran akan ketimpangan ini akhimya mendorong Dr. Wahidin Sudirohusodo untuk mengambil inisiatif melancarkan suatu aksi untuk mengumpulkan dana yang akan digunakan sebagai bea siswa bagi rakyat, khususnya rakyat Jawa yang ingin bersekolah.

(The educated group had a new vision of Indonesian nationalism. They wanted to change the view that regionalism is nationalism. The ideals of the Indonesian independence can therefore only be achieved when there is unity of the nation. Then the National Movement was borm, which was aimed to achieve an independent Indonesia. The figures of this educated group then set up the organization of the struggle, one of them was Dr. Wahidin Sudirohusodo. He was also instrumental in setting up Studie Fonds. Awareness of this disparity prompted Dr. Wahidin Sudirohusodo to take the initiative to launch an action to collect funds to be used as scholarships for people, especially the Javanese people who wanted to study.)

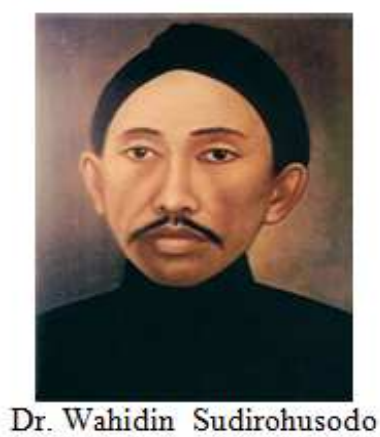

Perpecahan ini disebabkan dalam tubuh Sarikat Islam banyak dipengaruhi oleh organisasi-organisasi yang berhaluan kiri seperti ISDV (Indische Sosial Demokrache Vereeniging) yang dipimpin oleh DF Sneevliet. Banyak anggota-anggotanya yang terpengaruh, seperti Darsono, Tan Malaka, Semaun, Muso, dan Alimin, menyebabkan pecahnya Sarekat Islam menjadi dua aliran, yaitu aliran kiri dan aliran kanan. Pada tahun 1920 golongan kiri meleburkan diri dalam Partai Komunis Indonesia.

(This caused divisions in the body of Islamic States affected by many organizations such as the leftist ISDV (Indies Social Demokrache Vereeniging) led by DF Sneevliet. Many members were affected, like Reini, Tan Malaka, Sorry, Muso, and pious, causing the outbreak of the SI into two, which left and right groups. In 1920, the left group merged in the Communist Party of Indonesia.)

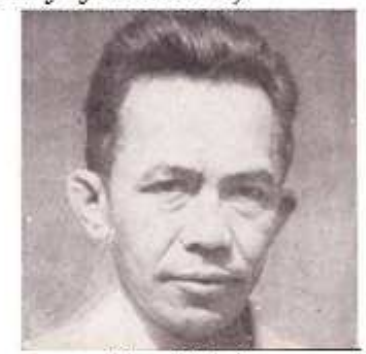

Tan Malaka

Fig. 1. Multicultural characters in a historical event

\section{Historical Event Location}

The Indonesian history textbooks present historical events from various regions in Indonesia, including popular resistance of Maluku in eastern Indonesia and popular resistance of Aceh in western Indonesia, as can be seen in Fig. 2.

\section{Cultural and Ethnic}

The Indonesian history textbook contains elements of culture and ethnic of the pluralistic Indonesian people by covering the whole territory of the Republic of Indonesia. It presents cultures and ethnics of Sumatra, Java, Bali, Kalimantan, Sulawesi and others. 
Perlawanan Rakyat Maluku (The resistance of the people of Maluku)

Perlawanan Kerajaan Temate (Maluku) memuncak setelah terjadinya pembunuhan terhadap Sultan di benteng Portugis pada tahun 1570. Persaingan berubah menjadi perlawanan rakyat Temate yang dipimpin oleh putra sultan Hairun yaitu Pangeran Baabullah yang selanjutnya menjadi Sultan. Benteng Santo Paulo berhasil dikepung dan pada tahun 1575 orang-orang Portugis menyerah.

(The resistance of Temate Kingdom (Maluku) peaked after the murder of the Sultan at the Portuguese fortress in 1570. The competition turned into a strike from Ternate people led by the son of Sultan Hairun, i.e. Prince Baabullah, who then became the sultan. Santo Paulo fortress was surrounded and the Portuguese surrendered in 1575).

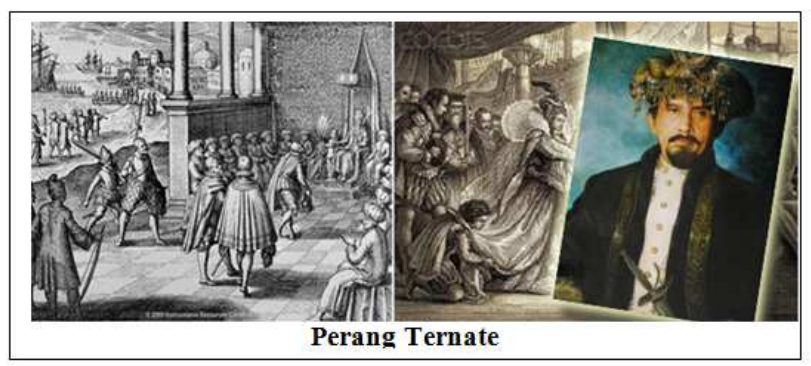

Perlawanan Rakyat Aceh(The resistance of the people of Aceh)

Pada Desember 1873 , Belanda mengirim pasukan ekspedisinya dengan membawa pasukan sebanyak 8.000 orang dibawah pimpinan Van Swieten. Kedatangan pasukan Belanda disambut oleh pasukan Aceh dan pertempuran sengit pun tidak dapat dihindarkan. Mereka berjuang menghadapi serbuan Belanda di bawah pimpinan Tengku Cik Di Tiro. Di daerah pantai barat, perlawanan rakyat Aceh dipimpin oleh Tengku Umar dan istrinya Cut Nyak Dien. Ia memimpin serangan terhadap pos-pos Belanda sehingga menguasai daerah sekitar Meulaboh pada 1882 .

(In December 1873, the Dutch sent an expedition squad by carying 8000 soldiers under the leadership of van Swieten. The Dutch arrival was welcomed with a fierce battle by Acehnese troops. The Acehnese fought the Dutch under the leadership of Teungku Cik Di Tiro. In the West coast, the Acehnese was led by Tengku Umar and his wife, Cut Nyak Dien. He led strikes against the Dutch posts until the area around Meulaboh was acquired in 1882).

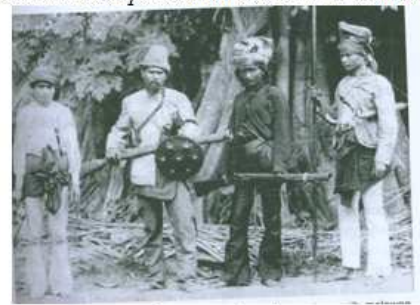

Perang Aceh

Fig. 2. Multiculturalism-based historical event location

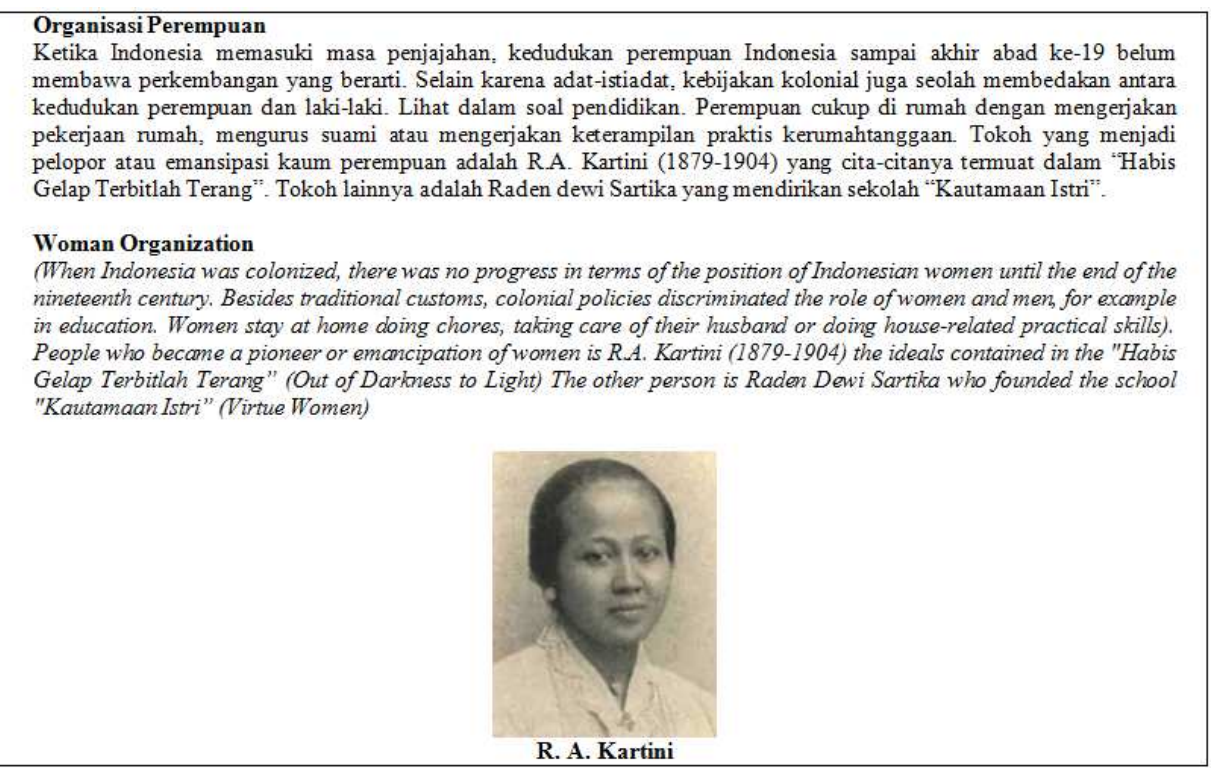

Fig. 3. Women in the Indonesian history textbook 
Table 1. Understanding of material and development of multiculturalism values

\begin{tabular}{|c|c|c|c|c|c|}
\hline \multirow{2}{*}{$\begin{array}{l}\text { Nr. Components } \\
\text { assessed }\end{array}$} & \multirow[b]{2}{*}{ Aspects assessed } & \multicolumn{4}{|c|}{ Assessment Results $(\mathrm{N}=207)$} \\
\hline & & Very good $(\%)$ & Good $(\%)$ & Enough $(\%)$ & Less $(\%)$ \\
\hline \multirow{6}{*}{$\begin{array}{l}\text { A. Understanding } \\
\text { of the material in } \\
2013 \text { curriculum }\end{array}$} & Fact & 65 & 27 & 12.00 & 6.00 \\
\hline & Concept & 55 & 24 & 12.00 & 9.00 \\
\hline & Principle & 46 & 26 & 14.00 & 14.00 \\
\hline & Procedure & 50 & 25 & 12.00 & 13.00 \\
\hline & Historical Thinking & 68 & 16 & 11.00 & 5.00 \\
\hline & Average score of component A & 56,20 & 23,60 & $12,20.00$ & 9.40 \\
\hline \multirow{10}{*}{$\begin{array}{l}\text { B. The development of the } \\
\text { multiculturalism values }\end{array}$} & Understanding the diversity of historical characters and events. & 65 & 15 & 10.00 & 10.00 \\
\hline & Understanding the diversity of the location of historical events. & 64 & 18 & 12.00 & 4.00 \\
\hline & Understanding diversity of culture and ethnic. & 65 & 19 & 12.00 & 6.00 \\
\hline & Understanding diversity of religion and gender & 70 & 15 & 8.00 & 7.00 \\
\hline & Appreciation & 65 & 15 & 10.00 & 10.00 \\
\hline & Tolerant & 60 & 19 & 15.00 & 6.00 \\
\hline & Cooperation & 48 & 40 & 18.00 & 2.00 \\
\hline & Unity & 70 & 21 & 8.00 & 1.00 \\
\hline & Average score of component B & 63,37 & 20,25 & $11,62.00$ & 5.75 \\
\hline & Average of total score & 59,78 & 21,93 & 11.91 & 7.58 \\
\hline
\end{tabular}

\section{Gender}

Indonesian history textbook does not only present men, but also women. The book contains the role of women's organizations and female warrior figure R.A. Kartini, as can be seen in Fig. 3.

\section{Test Results of Limited Number of Students}

To see aspects of the understanding of the content and development of the multiculturalism values, after use of the textbook, a test was administered to uncover understanding and attitude for learners. Aspects of understanding and development of the multiculturalism values are presented in Table 1.

The above table shows that learners have good skills in understanding the material and the values of multiculturalism fairly. Student's understanding of the 2013 curriculum (facts, concepts, principles, procedures and historical thinking) covers $56.20 \%$ of students; thus considered excellent. $23.60 \%$ of them considered good. The development of multiculturalism values covers $63.37 \%$ of students considered excellent and $20.25 \%$ of them considered good. In the aspect of understanding of the material according to the 2013 curriculum, learners have the best ability in understanding the facts and historical thinking. In the aspect of the development of the multiculturalism values, the most dominant is the understanding of diversity of historical characters and events, understanding the diversity of culture and ethnic, understanding the diversity of religion and gender, as well as respect and unity.

\section{Discussion}

A history textbook should meet the quality standards in terms of content (in line with curriculum), writing and presentation. In the aspect of content, the book should contain three elements: (a) Formal content (i.e., material from the discipline); (b) informal content (i.e., material taken from environments); and (c) students' response to informal as well as formal materials (Hanna and Lee, 1962). The contents and values developed in the textbook should meet the balanced needs of learners in an organized function, structure, humane and citizenship approach (Somantri, 2001). The content must be scientific, logical, systematic, appropriate with development levels of learners, using a spiral approach and including illustrations that are informative and attractive (Sjamsuddin, 2007).

In the book writing, there are at least five factors to be considered. First, the factual substance should be academically accountable (scientific). Second, the interpretation and/or explanation should be logical and systematic. Third, the presentation and rhetoric means that the narrative should match the age levels of learners based on theories of developmental psychology. Fourth, the introduction of the concepts has to use a "spiral" approach. Fifth, completeness of the illustrations, images, photos in setting and layout should be informative and attractive (Sjamsuddin, 2007).

Presentation of textbooks should pay attention to the learning strategy components and design of learning message. Components of instructional strategy include (1) pre-instructional activities, (2) presenting instructional materials, (3) eliciting performance, (4) providing feedback and (4) follow up activities, in the form of remedial and enrichment. On the other hand, the principles of learning messages design include (1) readiness and motivation, (2) attention directing devices), (3) student's active participation, (4) repetition and feedback (Gafur, 1986).

Development of textbooks should take into account the course goals, the general principles of textbook writing and integration the seven components of contextual learning (constructivism, questioning, inquiry, learning community, modeling, reflection and 
authentic assessment) with the components of learning strategies and principles of learning message design (Komalasari, 2010).

Second, the Indonesian history textbook that is based on multiculturalism values does not only present the subject matter contained in the curriculum. It should make learners learn materials and develop values of life, as well as a strong desire to apply them in daily life (Komalasari, 2012; Saripudin and Komalasari, 2015). The textbooks are required in schools. It should include learning materials in order to increase faith and piety, character and personality, ability to master science and technology, aesthetic sensitivity and ability, physical potential and health compiled based on national education standards (Komalasari, 2010).

Thus, the history textbook should develop values and character of reader in accordance with the context of the presented material. These values are developed in the framework of the establishment of nationalism and multiculturalism in line with the context of plural Indonesia (in ethnicity, tribe, religion, race and group). When various ethnic conflicts emerge, nationalism that carries national integration becomes questionable. It is because the local values have been ignored. Therefore, in the history education, multiculturalism is a necessity because a history textbook is a vehicle in the formation of the collective memory of a nation that has not been able yet to accommodate the interests. Writing of history in the context of ethnic relations can be performed by a multicultural approach. It can also be developed by writing local history. Pluralism of Indonesian people demands individual view called multiculturalism (Mulyana, 2009; Saripudin et al., 2014).

Third, multicultural education is focused on efforts to empower students and to improve the representation of minorities and culture in curricula and textbooks (Santrock, 2010). Integration of multiculturalism into an Indonesian history textbook accords with Banks (2002) idea of integrating multicultural values into curriculum. Following models of approaches can then be formulated.

\section{Contributions Approach or "Heroes and Holiday"}

This characteristics and approach is to develop material about heroism or figures as well as holiday celebrations or historical event in particular ethnicities. In the context of this research, the understanding of the multiculturalism value is through the history textbook. Therefore, students are not only introduced with the figures that are considered "brilliant" as a national hero or those considered elite, but may also the heroes who contributed to the particular regions (and tend to be ignored).

\section{Additive Approach or Ethnic Additive Approach}

In this approach, a teacher can give explanation about historical development of a particular ethnic without changing the structure of the curriculum. For example, in Bandung, the majority of the population is Sundanese, then it is appropriate for learners to understand the origins and traditions of Sunda. In Bandung, there is Sri Baduga Museum. Therefore, learners have to know who Sri Baduga is, what role of Sri Baduga was and what made his name used as a museum name in West Java.

\section{Transformative Approach}

In this approach, students are directed to understand concepts with various cultural and ethnic perspectives. For example, when students in West Java learn about "the Kingdom of Pajajaran", it is logical to teach them Sundanese culture and values like cageur, bageur, bener, pinter, singer, teger, tajeur/tanjeur, wanter, purusa ning $s a$ (heroic, honest, brave).

\section{Decision Making and Social Action Approach}

This approach integrates curriculum materials that include all elements of a transformative approach. However, it later adds a number of components that lead students to make decisions or take action related to concepts, issues, or problems. When students learn about the Industrial Revolution and its impacts on Indonesia, the students can be directed, for example, to study one section in the textbooks on the impact of the industrial revolution in the social field. It is among others the emergence of groups of employers and groups of workers and the gap between employers and workers in the following statement.

"In the industrialization activity, there are groups of workers (labor) and employers who own an industry or factory. Thus, in a society, there are new classes, i.e., employers (capitalists) who lived in luxury; and workers who live in poverty. With the advent of a class of entrepreneurs who live in luxury on the one hand and the workers who suffer on the other hand, there is a gap between employers and workers. Such conditions often trigger tensions followed by strikes to demand improvements of fortune"

Thus, for the fourth theory of Banks, after studying history, students are expected to think critically so that they can take important decisions to solve social problems. To establish and to maintain diversity in the harmony there should be necessary efforts to foster mutual respect, appreciation, existence acknowledgement and cooperation among ethnics, races, religions, social layers and economic gap (Wiriaatmadja, 2004).

Fourth, the results of limited testing of the book in schools indicate that learners demonstrate fair ability to understand material and the development of the multiculturalism values. Student's understanding of material can be considered excellent, which reinforces previous research that textbooks have an important role to play. Various studies show that textbook has a 
meaningful role in student achievements. In a World Bank (1995) on Indonesia, it is indicated that the level of book ownership of learners, as well as other facilities, is correlated with student achievements. The statement is reinforced by Supriadi (2000) who states that the book ownership level will positively and significantly impact learners' academic achievements. In the Philippines, the increase of the ratio of learner's book ownership from 1: 10 to 1: 2 in grade 1 and 2 significantly improves the student's learning outcomes (World Bank, 1995). The learning achievement in this case is not only about mastery of cognitive aspects (material according to curriculum), but also the affective aspect (development of code value) and historical thinking skills.

\section{Conclusion}

A multiculturalism-based Indonesian history textbook for high school integrates multiculturalism values by observing the principles of teaching history in the 2013 curriculum. It is to develop appropriate core and basic competence of 2013 curriculum, the principles of the preparation of textbook material, language and readability and graphics. The multiculturalism values developed in Indonesian history textbooks for SMA/MA Grade XI include diversity of historical characters and events, the occurrence of historical events, culture and ethnicity, religion and gender. The following models: Contributions Approach or "Heroes and Holiday", Additive approach or "ethnic additive approach, Transformative approach and Decision making and social action approach were adopted in developing the textbook.

The contents of the book include title of chapter, introduction, map of concepts and keywords. The materials presentation includes fact-concepts, principles, procedures-values of multiculturalism, competence, summary, reflection, authentic assessment, feedback and follow-up activities. The learners' understanding of material and the development of multiculturalism values can be classified as very good. Therefore, multiculturalism-based Indonesian history textbooks should be developed and made as a learning reference in school.

\section{Acknowledgement}

This research is a grant from the Ministry of Research, Technology and Higher Education of Indonesia. The author would like to express sincere appreciation for all supports provided.

\section{Funding Information}

This article was funded by the Ministry of Research, Technology and Higher Education of Indonesia.

\section{Author's Contribution}

Didin Saripudin: Designed the research plan and organized the study, data collection of the study sample, analysis and writing of the manuscript.

Kokom Komalasari: Participated in all results analysis, contributed to the drafting of the article and reviewing it critically for significant intellectual content.

\section{Ethics}

This Article is original and contains unpublished material. The Corresponding author confirms that all of the other authors have read and approved the manuscript and no ethical issues involved.

\section{References}

Banks, J.A., 2002. An Introduction to Multicultural Education. 3rd Edn., Allyn and Bacon, Boston, ISBN-10: 0205341020, pp: 161.

Borg, W.R. and M.D. Gall, 1989. Educational Research. 5th Edn., Addison-Wesley Longman, Incorporated, New York, ISBN-10: 0801303842, pp: 191.

Gafur, A., 1986. Desain Instructional: Suatu Langkah Sistematis Penyusunan Pola Dasar Kegiatan Belajar Mengajar. 1st Edn., Tiga Serangkai, Solo, pp: 95.

Hanna, P. and J. Lee, 1962. Content in the Social Studies. In: Social Studies in Elemenary Schools. Michaelis, J.U. (Ed.), NCSS, Washington D.C.

Hasan, S.H., 2012. Perkembangan kurikulum: Perkembangan ideologis dan teoritik pedagogis. Tersedia.

Komalasari, K., 2010. Pembelajaran Kontekstual: Konsep Dan Aplikasi. 1st Edn., Refika Aditama, Bandung, pp: 68.

Komalasari, K., 2012. The living values-based contextual learning to develop the students' character. J. Soc. Sci., 8: 246-251. DOI: $10.3844 /$ jssp.2012.246.251

Miles, M.B. and A.M. Huberman, 1984. Qualitative Data Analysis: A Source Book or. New Methods. Sage Publication, Beverly Hills, ISBN-10: 978-1452257877.

Mulyana, A., 2009. Pendekatan historiografi dalam memahami buku teks pelajaran sejarah.

Purwanta, H., 2012. Buku teks pelajaran sejarah SMA: Analisis isi dan wacana nasionalisme. M.Ed. Thesis, Universitas Pendidikan Indonesia, Bandung, Indonesia.

Santrock, J.W., 2010. Educational Psychology. 1st Edn., McGraw-Hill Education, New York, ISBN-13: 9780073378787, pp: 185.

Saripudin, D. and K. Komalasari, 2015. Living values education in school's habituation program and its effect on student's character development. New Educ. Rev., 39: 51-62. 
Saripudin, D., K. Komalasari and S. Moeis, 2014. The development of students' sociocultural values through wayang golek as a learning source in social studies. Res. Hum. Soc. Sci., 4: 129-136.

Sjamsuddin, H., 2000. Penulisan buku teks sejarah: Kriteria dan permasalahannya, historia. J. Pendidikan Sejarah.

Sjamsuddin, H., 2007. Penulisan Buku Teks dan Sejarah Lokal dalam Sejarah Lokal: Penulisan dan Pembelajaran di Sekolah. Salamina Press, Bandung.

Somantri, N., 2001. Menggagas Pembaharuan Pendidikan IPS. 1st Edn., Remadja Rosdakarya, Bandung, ISBN-10: 9796921162 , pp: 444.

Supardan, D., 2005 Pembelajaran sejarah, pendekatan multikultural, dan Integrasi Nasional di Indonesia. J. Pendidikan Sejarah, 6: 81-112.

Suparlan, P., 2005. Menuju Masyarakat Indonesia Yang Multikultural" Dalam Pendidikan Multikultural dan Revitalisasi Hukum Adat. 1st Edn., Departement Kebudayaan dan Pariwisata, Jakarta, pp: 24.
Supriadi, 2000. Anatomi Buku Sekolah Di Indonesia: Problematik Penilaian, Penyebaran, Dan Penggunaan Buku Pelajaran, Buku Bacaan, Dan Buku Sumber. Adicita, Yogyakarta, ISBN-10: 979924630X, pp: 314.

Tarigan, 1986. Telaah Buku Teks SMA. 1st Edn., Karunia, Jakarta, pp: 13.

Tilaar, H.A.R., 2005. Pendidikan dalam Multikulturalisme" dalam Pendidikan Multikultural dan Revitalisasi Hukum Adat. Departemen Kebudayaan dan Pariwisata, Jakarta.

Wiriaatmadja, R., 2004. Multicultural perspective in teaching history in the Chinese Indonesian student. J. Pendidikan Sejarah, 5: 62-75.

World Bank, 1995. Indonesia: Book and reading development project. Staff, Appraisal. 